\title{
Silver nanoparticle Bacteriostatic activity Assessment against Extended- Spectrum Beta-Lactamase Producing Uropathogenic Klebsiella pneumonia
}

\section{Payman Akram Hama saeed}

Department of Biology, College of Education , University of Salahaddin - Erbil, Kurdistan Region, Iraq.

E-mail: Paymanakram@yahoo.com

\section{Shayma Jabar Hyder}

Department of Biology , College of Education, University of Salahaddin -Erbil, Kurdistan Region, Iraq.

E-mail: Shayma.jabar@gmail.com

\begin{abstract}
:
The aims: Screen for the Extended-Spectrum Beta-Lactamase producing Klebsiella pneumonia from urinary tract infection UTI patients phenotypically and molecularly, also testing different sizes of silver nanoparticles as antibacterial for the resistance isolates.

Methodology: Vitek Extended-Spectrum Beta-Lactamase test, molecular confirmed ESBL-producing isolates were checked by PCR for the presence of $A m p C$ and bla $a_{\text {CTX- } M}$ genes. Flat well microtiter plates were used for packing of antibacterial activity of silver nanoparticles. This study included 85 urine samples were collected from patients that admitted to the "Rizgary Hospital" in Erbil province from 15 June to 15 December 2018. Antibiotic sensitivity test of all isolates to (Ampicillin, Ampicillin/sulbactam Cefazolin, Ceftazidime Ceftriaxone, Cefepime, Imipenem, Nafcillin and Nitrofurantoin )antibiotics were tested by the disc-agar method as standardized by the National Committee for Clinical laboratory Standards (2006).

Results: Out of 51 tested isolates of Klebsiella pneumonia, 11 (21.6\%) were Extended-Spectrum Beta-Lactamase Producers. Their antibiotic resistance profile showed the rate of resistance isolates was (100\%) to Ampicillin, Cefazolin, Ceftazidime and Ceftriaxone and (90\%) to Cefepime .In addition the susceptibility to Imipenem was (72.7\%) of isolates. The bands of the AmpC and bla СтХ-м genes was noted in (42.9\%) samples and the remain samples $(57.1 \%)$ were negative for both genes. The Minimum Inhibitory Concentration during incubation of Non ESBL producer - ESBL producer isolates in series concentrations of silver nanoparticles size (20 nm) was between $(625-2500) \mu \mathrm{g} / \mathrm{ml}$ and for size $(90 \mathrm{~nm})$, it was $(1250) \mu \mathrm{g} / \mathrm{ml}$ for non ESBL producer and not affected ESBL producer isolates. The increased percentage rates of $\beta$-lactamase producing Klebsiella species were seen which was considered as an alarm, due to limitation in treatment options for UTI. It was appeared that Imipenem currently is
\end{abstract}


the main available antibiotic for UTI treatment as a drug of choice. It was noticed that different sizes of silver nanoparticles showed antibacterial activity for ESBL producing isolates.

Recommendation : Future studies needed on other types and size of nanoparticles on different types of bacterial isolates from different clinical sources which will enable the monitoring of trends overtime.

Keywords: Silver nanoparticle, Klebsiella pneumonia, ESBL, UTI. 


\section{Introduction :}

Extended Spectrum Beta- Lactamase producing organisms causing urinary tract infections (ESBL-UTI) .The spread of ESBL-producing Enterobacteriaceae (ESBL-PE) has dramatically increased worldwide. E.coli and $K$. pneumonia are common producers of ESBL, and they generally cause bacteraemia and urinary tract infection .ESBL producing Klebsiella species seem to account for most nosocomial outbreaks [1]

The nanoparticles (NPs) are efficiently being used as antibacterial agents. Some studies have been reported which displays the antibacterial nature of NPs against gram negative and gram positive bacteria, mycobacteria and fungi [2]. One of the accepted relationships between NPs and antibacterial activity is NPs can complement and support traditional antibiotics "as a good carrier." [3]. In addition "Nanomaterials as antibacterial complements to antibiotics are highly promising and are gaining large interest as they might fill the gaps where antibiotics frequently fail" [4].

The antibacterial activity of Silver nanoparticles (AgNPs ) against gram-negative bacteria, such as E. coli was reported [5].Other study was evaluated that AgNPs exhibited high bactericidal activity against ampicillin-resistant E. coli $\mathrm{O} 157: \mathrm{H7}$, multidrug-resistant Pseudomonas aeruginosa and erythromycin-resistant Streptococcus pyogenes [6]. Staphylococcus aureus and E. coli also were shown to be substantially inhibited by AgNPs [7].Moreover, the bactericidal activity of AgNPs against the pathogenic, multidrug-resistant (MDR) as well as multidrug-susceptible strains of bacteria was studied by many scientists, and it was proved that the AgNPs are the powerful weapons against the MDR bacteria like Pseudomonas aeruginosa, Methicillin-resistant Staphylococcus aureus (MRSA), ampicillin-resistant E. coli, vancomycin-resistant Staphylococcus aureus (VRSA) and erythromycin-resistant Streptococcus pyogenes [8]. The antimicrobial activity of AgNPs in strains of S. aureus resistant to a large number of antibiotics was tested and underscored [9]. Other study were proved AgNPs as good antimicrobial efficacy againsta broad range of gram-positive and gram-negative bacteria, yeast, molds and viruses [10]. The present study conducted to evaluate the prevalence and antimicrobial resistance pattern of ESBL-producing $K$. pneumoniae among UTI infections patients, determination of the minimum inhibitory concentration (MIC) of different size of silver nanoparticles against these isolates and finally investigation the prevalence of the beta lactamase $A m p C$ and bla $_{\text {СтX-м }}$ genes responsible for resistance in isolates under study by PCR . 


\section{Materials and Methods}

\section{1-Sample collection, Isolation and Identification of $K$. pneumonia:}

A total of 85 midstream urine samples were collected form suspected UTI infected patients (inpatients and out patients) with specialist physicians in Rizgary Hospital in Erbil City during the period between 15 June, to 15 December, 2018. Patients who received antibiotics within the past two weeks were excluded.

A $10 \mu \mathrm{l}(0.01 \mathrm{ml})$ of mixed urine sample was inoculated on MacConkey agar and incubated at $37^{\circ} \mathrm{C}$ for 24 hours. Positive culture isolates were preliminarily screened by their colony morphology, Gram-staining techniques Further identifications of isolates were made by conformation of motility ,Catalase ,Oxidase ,Urease ,H2S , Motility ,DNase ,Indole, Citrate, Methyl Red and Voges Proskauer tests.

Subcultures were incubated at $37^{\circ} \mathrm{C}$ for 24 hours then single pure colonies were isolated, and transferred to slant nutrient agar tubes for preservation and performing other tests [11].

\section{2- Detection of ESBL producer isolates by VITEK 2 system:}

The automated VITEK 2 system was depended for detection of extended-spectrum b-lactamases (ESBLs) producer Klebsiella pneumoniae. Moreover, isolate characterization and antimicrobial susceptibility testing were achieved using VITEK 2 system through ID-GNB cards, according to the manufacturer's instructions. The ESBL screening test utilizes the growth response to ceftazidime, cefepime, and cefotaxime in combination with or without clavulanic acid . All results were interpreted by using the Advanced Expert System (software version VT2-R04.03). [12] and [13].

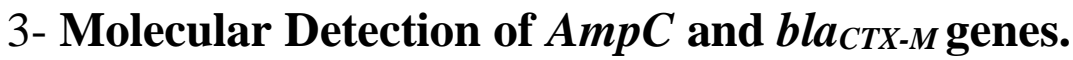

From the sum total of isolates analysed (11 phenotypically confirmed ESBL producers only 6 randomly selected and were subjected to polymerase chain reaction (PCR) analysis. The PCR amplification of bla genes, including bla $_{\text {СтX-M }}$ bla $A m p C$ were carried out with GoTaq ${ }^{\circledR}$ Green Master Mix using primers listed in (Table 1). DNA extraction: A single colony from overnight incubated pure culture was suspended into $1 \mathrm{ml}$ of distilled water, centrifuged at $14000 \mathrm{xg}$ for $2 \mathrm{~min}$, then the supernatant discarded, after that $120 \mu \mathrm{L}$ of lysostaphin $(10 \mathrm{mg} / \mathrm{L}$; Sigma) was added. DNA extracted using mini DNA extraction kit (Promega) according to manufacture instructions. PCR were carried out using thermal cycler (Eppendorf Master cycler Gradient) depending on [14 \& 15). The PCR mix was prepared in a volume of $25 \mu$ l containing $4 \mu \mathrm{l}$ DNA template, $12.5 \mu \mathrm{l}$ Go Taq Green Master (Promega, CA) 2 
$\mathrm{ml}$ of $10 \mathrm{X}$ PCR buffer (Sigma, Aldrich), $1.5 \mathrm{mM} \mathrm{MgCl} 2,0.6 \mu 12 \mathrm{mM}$ dNTPs (ferments), $1 \mu \mathrm{l}$ of (10 Pmol $\backslash \mu \mathrm{l})$ of each primer volume made up to $25 \mu \mathrm{l}$ with distilled water. The cycling conditions used and product size for two different PCR are shown in (Table:2/Fig-1 \& 2). The amplified product was subjected to $1.5 \%$ agarose gel electrophoresis, and visualized under UV after ethidium bromide staining.

Table 1: Primer used for the amplification of $A m p C$ abd bla

\begin{tabular}{|c|c|c|c|}
\hline Primers & Sequence $\left(5^{\prime} \rightarrow 3^{\prime}\right)$ & $\begin{array}{c}\text { Lengt } \\
\text { h }\end{array}$ & $\begin{array}{c}\text { (bp } \\
\text { ) }\end{array}$ \\
\hline$A m p C-\mathrm{F}$ & $\begin{array}{l}\text { AATGGGTTTTCTACGGTC } \\
\text { TG }\end{array}$ & 20 & 191 \\
\hline$A m p C-\mathrm{R}$ & $\begin{array}{l}\text { GGGCAGCAAATGTGGAG } \\
\text { CAA }\end{array}$ & 20 & \\
\hline bla $_{C T X-M-\mathrm{F}}$ & $\begin{array}{l}\text { AATCACTGCGTCAGTTCA } \\
\text { C }\end{array}$ & 19 & 701 \\
\hline bla $_{C T X-M^{-}} \mathrm{R}$ & $\begin{array}{l}\text { TTTATCCCCCACAACCCA } \\
\text { G }\end{array}$ & 19 & \\
\hline
\end{tabular}

Table 2 : PCR Conditions for amplification of AmpC and bla $a_{C T X-M}$ genes

\begin{tabular}{|c|c|c|c|c|c|c|}
\hline $\begin{array}{c}\text { Gene } \\
\text { Detected }\end{array}$ & $\begin{array}{c}\text { Denaturation } \\
\text { Time/temp }\end{array}$ & $\begin{array}{l}\text { Annealing } \\
\text { Time/temp }\end{array}$ & $\begin{array}{l}\text { Extension } \\
\text { Time/temp }\end{array}$ & $\begin{array}{c}\text { No. } \\
\text { of } \\
\text { cycles }\end{array}$ & Product & $\begin{array}{l}\text { Depending } \\
\text { Reference }\end{array}$ \\
\hline$A m p C$ & $\begin{array}{c}94^{\circ} \mathrm{C} \\
1.5 \text { minute }\end{array}$ & $\begin{array}{c}57^{\circ} \mathrm{C} \\
30 \text { second }\end{array}$ & $\begin{array}{c}72^{\circ} \mathrm{C} \\
10 \text { minute }\end{array}$ & 30 & $191 b p$ & 14 \\
\hline$b l a_{C T X-M}$ & $\begin{array}{c}94^{\circ} \mathrm{C} \\
30 \text { second }\end{array}$ & $\begin{array}{c}50^{\circ} \mathrm{C} \\
30 \text { second }\end{array}$ & $\begin{array}{c}72^{\circ} \mathrm{C} \\
7 \text { minute }\end{array}$ & 35 & $701 b p$ & 15 \\
\hline
\end{tabular}




\section{4-Minimum Inhibitory Concentration (MIC) of Nanoparticles against Klebsiella pneumonia isolates}

\section{Stock solutions of Nanoparticles:}

Commercially synthesized AgNPs were purchased from M K Impex Corp., CANADA. The reported "as manufactured" in small glass container labeled with the quantity and size of nanoparticles AgNPs $\backslash 20,90 \mathrm{~nm}$. Preparation Stock solution was achieved according to the method mentioned by other investigators. Ten $\mathrm{ml}$ of deionizer water was added to100 $\mathrm{mg}$ of AgNPs and requested vigorously for 5 minutes to break the bloc of nanoparticles to get a homogeneous solution and then sterilized by autoclaved at $121 \mathrm{C}^{0}$ for 15 minutes and cool in temperature room for a final concentration of stocks $10 \mathrm{mg} / \mathrm{ml}[16]$. .

\section{Inoculums preparation:}

The 18 hours cultures plate from all Klebsiella pneumonia isolates were prepared. Single colonies from each isolated plate were transferred to $5 \mathrm{ml}$ sterile suspension media to obtain $106 \mathrm{cfu} / \mathrm{ml}$, which were also adjusted with $0.5 \mathrm{McF}$ arland tube.

\section{Procedure:}

Ninety six flat well microtiter plates were used for packing of bacteriostatic activity of nanoparticles according to the methods described by Amsterdam [17]:-

1- Mueller-Hinton broth $100 \mu \mathrm{l}$ was putted in each wells of a microtitre plate.

2-One hundred microliters of $5000 \mu \mathrm{g} / \mathrm{ml}$ nanoparticle (size $20 \mathrm{~nm}$ ) was transferred into the well 1 in row A then mixed with broth by sucking up and down 6-8 times. This makes well 1 a twofold dilution of stock (i.e. $2500 \mu \mathrm{g} / \mathrm{ml}$ ).

3-From well 1,100 $\mu 1$ was transferred to well 2 in the same row. This makes well 2 a twofold dilution of well 1. This procedure was repeated down to well 10 only and the concentrations $(5000,2500,1250,625,312.5,156.25$, $78.125,39.0625,19.531,9.531) \mu \mathrm{g} / \mathrm{ml}$, and $100 \mu \mathrm{l}$ from well 10 was discarded .

4-The same collection of tips was used for the size $90 \mathrm{~nm}$ of nanoparticles in different rows with same plate. The plate inoculation was performed by adding $5 \mu \mathrm{l}$ of bacterial suspension into wells in columns 1 to 10 [well 11 contain broth and bacterial suspension (positive control ). well 12 only contain broth without bacterial suspension (negative control). All plates were incubated at $37 \mathrm{C}^{\circ}$ for $24 \mathrm{hrs}$. After incubation, the MIC was determined as described previously. 


\section{Results and Discussion}

Out of 85 urine sample, $56(65.9 \%)$ showed bacteriuria (dark pink mucoid colonies ,lactose fermentation ) and 29 $(34.1 \%)$ were non-bacteriuria as shown in Table (3).

Table 3: Number and percentage of positive and negative growth cultures in urine samples.

phenotypic

\begin{tabular}{|c|c|c|}
\hline Urine samples Culture & N. & $\%$ \\
\hline Positive & 65 & 65.9 \\
\hline Negative & 29 & 34.1 \\
\hline Total & 85 & 100 \\
\hline
\end{tabular}

characteristics

of

isolates was reported. VITEK 2 Compact Instrument, using the GNI (Gram-Negative Identification) card according to the manufacturer instructions was used, and the biochemical characters were summarized in (Table 4).

\section{Table 4:}

phenotypic characterizes of $K$. pneumonia

\begin{tabular}{|c|c|}
\hline Tests & Results \\
\hline Gram stain/ Shape & -ve/Rod \\
\hline Catalase & +ve \\
\hline Oxidase & -ve \\
\hline Urease & +ve \\
\hline H2S & -ve \\
\hline Capsule & $+v e$ \\
\hline Motility & -ve \\
\hline DNase & -ve \\
\hline Indole & -ve \\
\hline Citrate & $+\mathrm{ve}$ \\
\hline MR (Methyl Red) & -ve \\
\hline VP (Voges Proskauer) & $+\mathrm{ve}$ \\
\hline Lactose & $+\mathrm{ve}$ \\
\hline
\end{tabular}

Using the Vitek ESBL test, screening for the resistance profile of ESBL-producing (11 isolates) was obtained and showed in (Table 5). The rate of resistance isolates was (100\%) to Ampicillin, Cefazolin, Ceftazidime and Ceftriaxone and (90\%) to Cefepime .In addition the susceptibility to Imipenem was (72.7\%) of isolates . 
Table 5: MIC and Resistance profile of ESBL- producing $K$. pneumonia isolates by Vitek ESBL test.

\begin{tabular}{|c|c|c|c|}
\hline Antimicrobial & $\begin{array}{l}\mathrm{N}(\%) \text { of } \\
\text { isolates }\end{array}$ & MIC & $\begin{array}{l}\text { Inter } \\
\text { preta } \\
\text { tion }\end{array}$ \\
\hline ESBL & 11/21.6 & POS & + \\
\hline Ampicillin & $11(100 \%)$ & $>=32$ & $\mathbf{R}$ \\
\hline $\begin{array}{l}\text { Amoxicillin/Clavulanic } \\
\text { Acid }\end{array}$ & $3(27.3)$ & $>=32$ & $\mathbf{R}$ \\
\hline Ampicillin /Sulbactam & $3(27.3)$ & $>=32$ & $\mathbf{R}$ \\
\hline Piperacillin/Tazobactam & $2(18.2)$ & 32 & I \\
\hline Cefazolin & 11(100) & $>=64$ & $\mathbf{R}$ \\
\hline Ceftazidime & 11(100) & 16 & ${ }^{\times} \mathbf{R}$ \\
\hline Ceftriaxone & 11(100) & $>=64$ & $\mathbf{R}$ \\
\hline Cefepime & $10(90.9)$ & 2 & ${ }^{x} \mathbf{R}$ \\
\hline Ertapenem & $5(45.5)$ & $<=0.5$ & $\mathbf{S}$ \\
\hline Imipenem & $8(72.7)$ & $<=0.25$ & $\mathbf{S}$ \\
\hline Gentamicin & $5(45.5)$ & $>=16$ & $\mathbf{R}$ \\
\hline
\end{tabular}

\section{R: resistant S: sensitive I: intermediate POS:positive}

Out of $51 \mathrm{~K}$. pneumoniae isolated $16(31.4 \%)$ in males and $35(68.6 \%)$ in females screened for bacteria commonly reported in urinary tract infection most of the isolate were non ESBL producer 40 ( 78.4\%) and ESBL producer were identified at a lower frequency reached 11(21.6\%). From (11) ESBL producers, 7 (63.6\%) were isolated from patients older than 50 years and 4 (36.4\%) from age groups15- 49 years old as shown in Table (6). Most of ESBL-producing K. pneumonia 7(63.6\%) were isolated from inpatients who have history of healthcare contact . 
Table 6: Distribution of ESBL-producing and non-ESBL-producing Klebsiella pneumonia isolates

\begin{tabular}{|c|c|c|c|c|}
\hline \multicolumn{2}{|c|}{ Characteristics } & $\begin{array}{l}\text { Total } \\
\text { isolate } \mathbf{N}(\%)\end{array}$ & $\begin{array}{l}\text { ESBLs- } \\
\text { positive } \\
(n=11)\end{array}$ & $\begin{array}{l}\text { ESBLs- } \\
\text { negative } \\
(n=40)\end{array}$ \\
\hline \multicolumn{5}{|c|}{$\begin{array}{l}\text { Age groups } \\
\text { and sex }\end{array}$} \\
\hline \multirow{4}{*}{$\begin{array}{l}\text { Age } \\
\text { Sex }\end{array}$} & $15-49$ & $37(72.5 \%)$ & $4(36.4 \%)$ & $33(82.5 \%)$ \\
\hline & $\geq 50$ & $14(27.5 \%)$ & $7(63.6 \%)$ & $7(17.5 \%)$ \\
\hline & Female & $35(68.6 \%)$ & $8(72.7 \%)$ & $29(72.5 \%)$ \\
\hline & Male & $16(31.4 \%)$ & $3(27.3 \%)$ & $11(27.5 \%)$ \\
\hline \multicolumn{5}{|c|}{ Distribution } \\
\hline \multicolumn{2}{|c|}{ Out patients } & $40(78.4 \%)$ & $4(36.4 \%)$ & $27(67.5 \%)$ \\
\hline \multicolumn{2}{|c|}{ In patients } & $11(21.6 \%)$ & $7(63.6 \%)$ & $13(32.5 \%)$ \\
\hline
\end{tabular}

In the current study, the ESBL-producing phenotype were detected in $21.6 \%$ of the obtained isolates, which was higher than results obtained in Taiwan by other investigators [18 \& 19] who reported that the ESBL producers from outpatients were $14.3 \%$. In contrast, the percentage of ESBLs observed in our study were lower (23\%) than previous observations reported in Southwest Ethiopia [20], also from Saudi Arabia which was (42.38\%) [21] moreover, the percentage was higher in Tanzania (45.2\%) [22]. The hospital environment has an important role in maintenance of ESBL-producing organism [23]. Moreover, higher rate of ESBLs producers were also observed in inpatients in Saudi Arabia hospital [24] .

polymerase chain reaction assay confirmed that out of the six isolate, $3(50 \%) \%$ ) harbored AmpC and blaCTX-M genes as shown in the Figure (1) and Figure( 2). The remainder were negative for AmpC and $b_{l} a_{C T X-M}$ genes and resistance to many antibiotics this might be due to another gene belonging to the ESBL group but located on plasmids which is not investigated in our study. These finding was in agreement with other resechers who found that the chromosomally encoded AmpC $\beta$-lactamases are rare(25). A study on the ability of Klebsiellae isolates to $A m p C$ production were revealed that 9 (30\%) isolates produce AmpC $\beta$-lactamase. While confirmed PCR amplification results have shown that only six Klebsiellae isolates possess AmpC $\beta$ - lactamase gene. [26]. PCR remains the gold standard for detection of ESBL genes. 


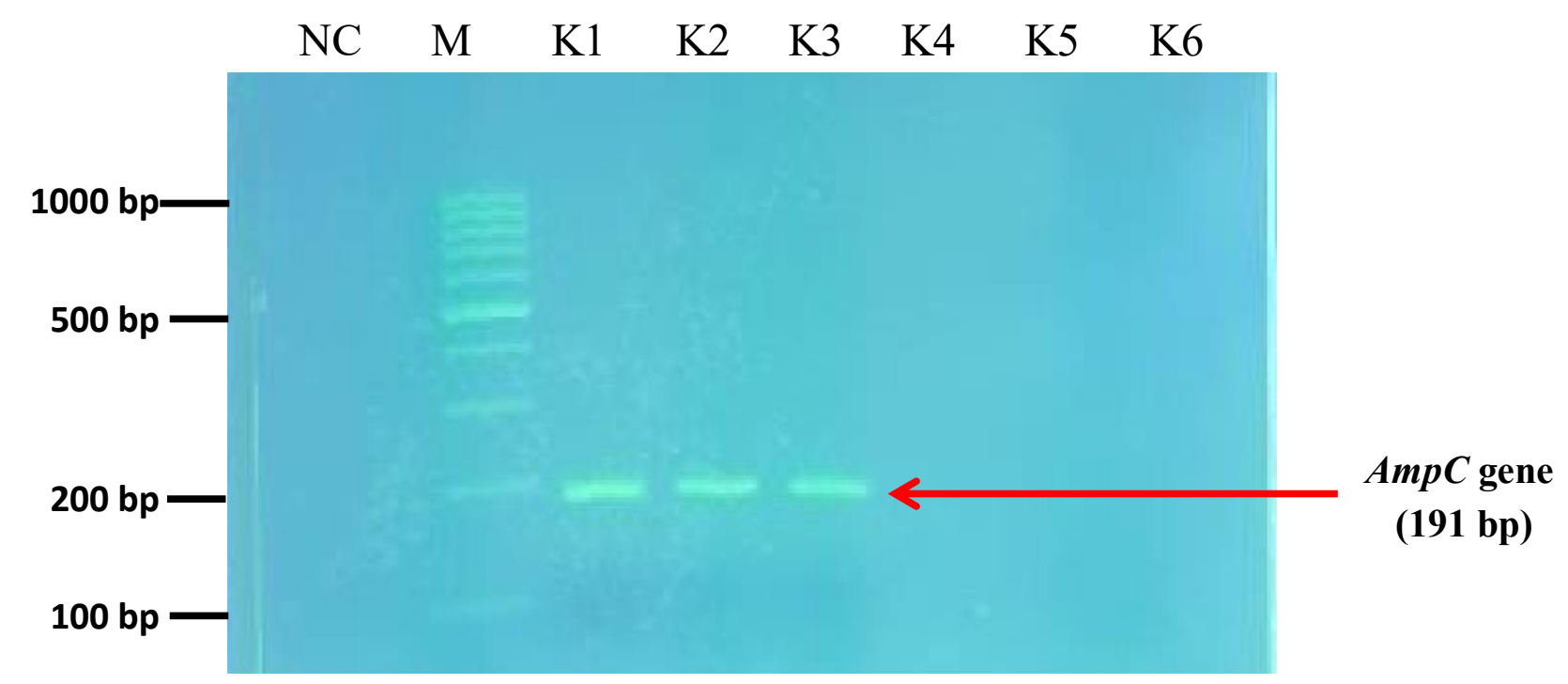

Figure (1) :The band site at the extent of $A m p C$ gene in $191 \mathrm{bp}$ for Klebsiella pneumonia isolates (K1-6). Lane NC: Negative control , Lane $M$ :Ladder (100bp), Lanes 1,2 and 3 Positive samples, Lanes 4,5 and 6 Negative samples

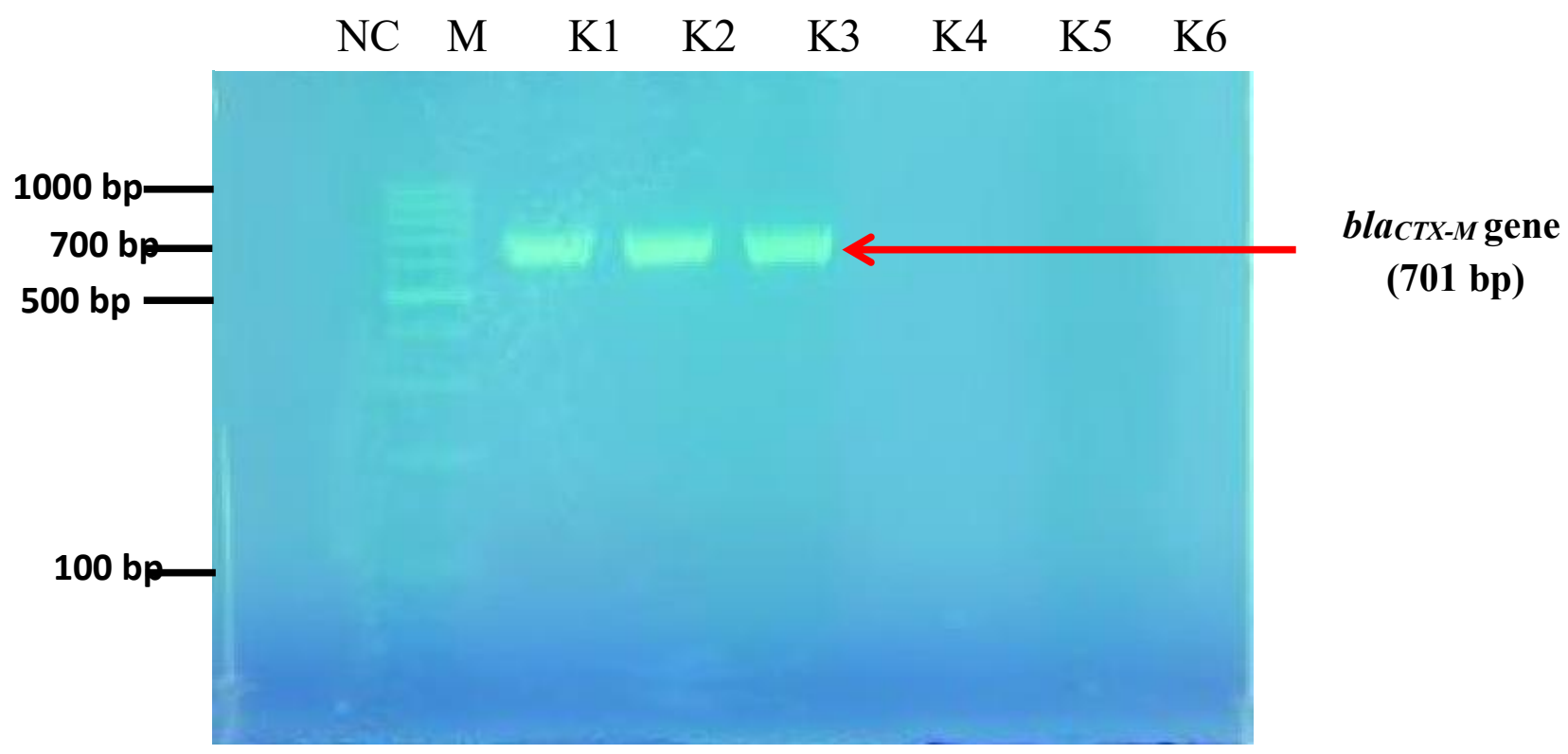

Figure (2) :The band site at the extent of blactX-M gene in 701bp for Klebsiella pneumonia isolates (K1-6). Lane NC: Negative control, Lane M :Ladder (100bp) , Lanes 1,2 and 3 Positive samples, Lanes 4, 5 and 6 Negative samples 
Incubation of ten isolates of each non ESBL producer and ESBL producer K. pneumonia in series concentrations of AgNps size20nm for 48 hours showed that the bacteriostatic effect was between $(625-2500) \mu \mathrm{g} / \mathrm{ml}$ and for AgNP size 90nm was (1250) $\mu \mathrm{g} / \mathrm{ml}$ for non ESBL producer while bacterial growth was recorded for ESBL producer isolates as shown in Table (7).

Table (7) The Minimum Inhibitory concentration (MIC) of Silver nanoparticles against K.pneumonia .

\begin{tabular}{||c|c|}
\hline \multirow{2}{*}{ AgNPs Size } & MIC $(\mu \mathrm{g} / \mathrm{ml})$ of isolates \\
\cline { 2 - 2 } & Non ESBL producer - ESBL producer \\
\hline AgNPs size 20nm & $625-2500$ \\
\hline AgNPs size 90nm & $1250-+$ \\
\hline
\end{tabular}

\section{$+=$ Bacterial growth}

The bactericidal mechanisms of AgNPs are not fully understood [27], although, the antimicrobial activity of AgNps is mainly based on different mechanisms including release of $\mathrm{Ag}$ ions which bind to electron donor groups in molecules containing sulphur, oxygen or nitrogen; disruption of DNA replication and oxidative stress through the catalysis of reactive oxygen species (ROS) formation [28\& 29]. Silver ions or small AgNPs can easily enter the microbial body causing the damage of its intracellular structures. As a consequence ribosomes may be denatured with inhibition of protein synthesis, as well as translation and transcription can be blocked by the binding with the genetic material of the bacterial cell [30]. 


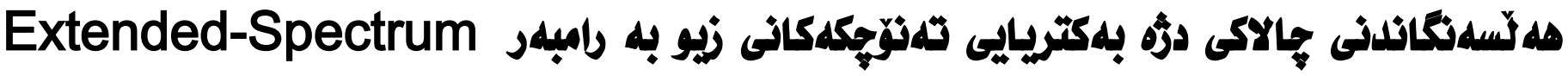

\section{Beta-Lactamase Producing Klebsiella pneumonia}

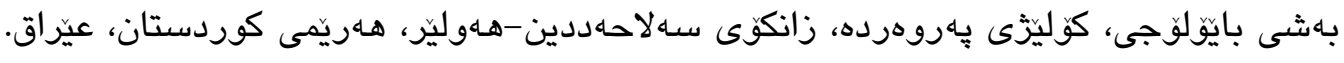

Paymanakram@yahoo.com

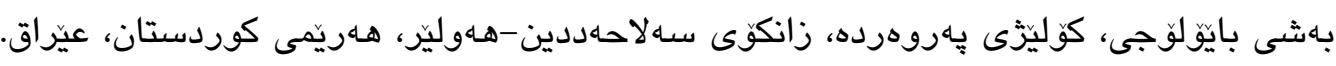

Shayma.jabar@gmail.com

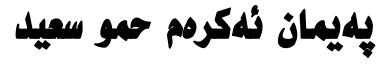

نئيمهيل:

تُمليعاء جهبار حdيلدهر

نئيمهيلّ:

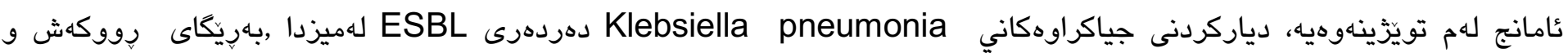

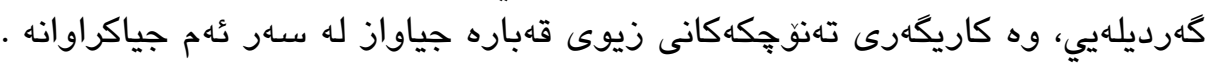

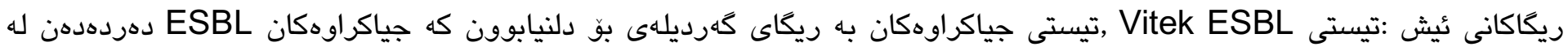

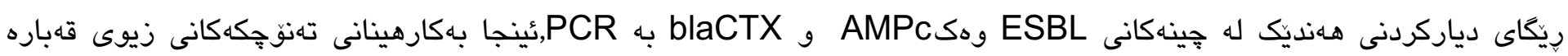
جياواز وهك دزه بـكتريا .

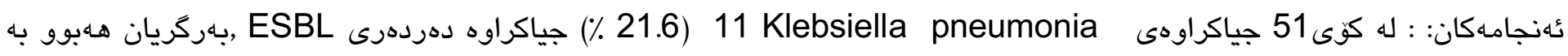

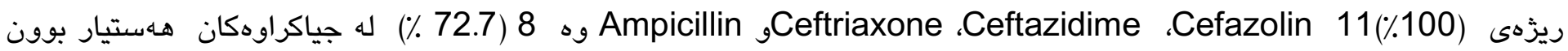
Imipene بو رئو

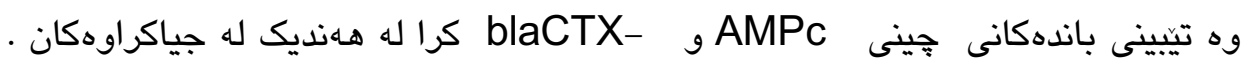

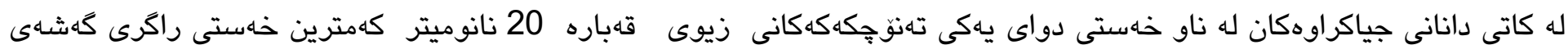

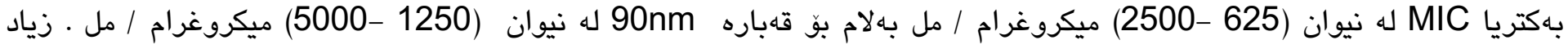

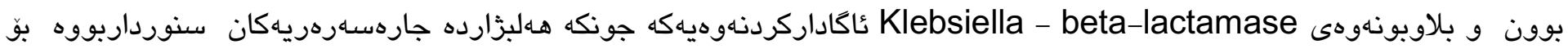
نهخوّشهانى هاهوكردنى كؤئهندامى ميز ،وه دهتوانريت له ئيستادا دزه تهنى

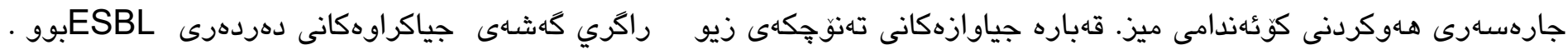
راسباردهان : راسباردهى تويزينهوهى داهاتوويى دهكهين لهاهر جورهكان و قهباره جياوازهكان تهنوجكهانى تر بكريت له سهر

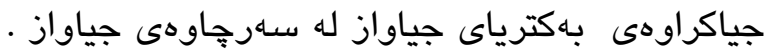
كليله وشُهكاز : تهنى نانويى زيو , ESBL , Klebsiella pneumonia 


\section{Extended-Spectrum Beta-Lactamase تقييم النشاط الثشيط البكتيري للجسيمات الناثوية الفضية تجاه Producing Klebsiella pneumonia}

$$
\begin{aligned}
& \text { قسم علوم الحياة ، كلية التربية، جامعة صلاح الدين-اربيل، إقليم كردستان ، العراق. } \\
& \text { Paymanakram@yahoo.com } \\
& \text { قسم علوم الحياة ، كلية التربية، جامعة صلاح الدين-اربيل، إقليم كردستان ، العراق. }
\end{aligned}
$$$$
\text { Shayma.jabar@gmail.com }
$$

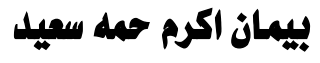

نيميل:

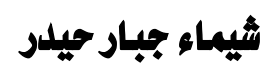

ئيميل :

| إنغاصמג |

الهدف من هذه الدراسة :هو الكشف عن عزلات Klebsiella pneumonia المنتجة لESBL والمعزولة من مرضى التهاب المسالك البولية، مظهريا و جزيئيا ، وتاثير دقائق الفضة مختلفة الأحجام على هذه العزلات .

طرائق العمل: احتوت فحص Vitek ESBL , فحص العزلات جزيئيا للتاكد من إنتاجها لـ ESBL من خلال التحري عن جين بواسطة تفاعل البوليميز المتسلسل. ثم استخدام دقائق الفضة بأحجام مختلفة كمضاد بكتيري بطريقة .microtiter plates

النتائج : من مجموع51 عزلة 11 Klebsiella pneumonia (21.6 \%) عزلة كانت منتجة لـ ESBL، مقاومة (100\%) Imipenem بينما كانت Ampicillin و Ceftriaxone ،Ceftazidime ،Cefazolin . لوحظت حزم جين AMPc و في بعض العزلات.

عند حضن العزلات بتزاكيز متسلسلة من AgNPs حجم 20 نانوميتز، كان تركيز الأدنى المثبط MIC بين (625 -2500) ميكروغرام

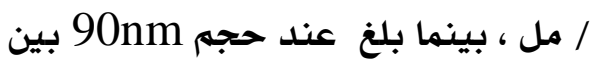

(5000-1250) ميكروغرام/مل. إنّ الانتشار المتزايد لـ Klebsiella -beta-lactamase يعد إنذاراً؛ لأنّ هناك خيارات علاجية محدودة لمرضى المسالك البولية و ميكرورات

التوصيات: نوصي بلدراسات مستقبلية على أنواع وأحجام الجسيمات النانوية الأخرى وتاثيرها على عزلات بكتيرية مختلفة النوع والمصدر .

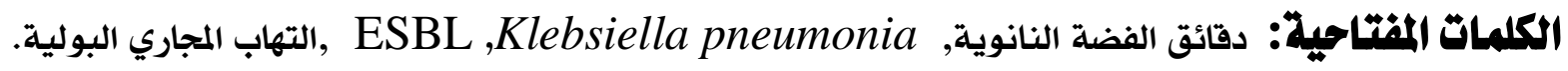




\section{References:}

Foxman, B. (2010). The epidemiology of urinary tract infection. Nature Reviews Urology, 7, 653.

Wang,L. Chen Hu,and Longquan Shao (2017).The antimicrobial activity of nanoparticles: present situation and prospects for the future. International Journal of Nanomedicine . Volume 12 :1227-1249.

Zhang L, Pornpattananangku D, Hu CM, Huang CM.

Development of nanoparticles for antimicrobial drug delivery. Current Medicinal Chemistry, 17(6):585-94.

Beyth,N. Yae Houri-Haddad, Avi Domb, Wahid Khan, and Ronen Hazan (2015). Alternative Antimicrobial Approach:Nano-Antimicrobial Materials Review Article Evidence-Based Complementary and Alternative Medicine.

Morones, J. R., Elechiguerra, J. L., Camacho, A., Holt, K., Kouri, J. B., Ramirez, J. T. and Yacaman, M. J. (2005). The bactericidal effect of silver nanoparticles. Nanotechnology.16, 2346.

Lara, H. H., Ayala-Nunez, N. V., Turrent, L. D. C. I. \& Padilia, C. R. (2010). Bactericidal effect of silver nanoparticles against multidrug-resistant bacteria. World Journal of Microbiology and Biotechnology. 26, 615-621.

Kim, S.-H., Lee, H.-S., Ryu, D.-S., Choi, S. J.and Lee, D.-S. (2011). Antibacterial activity of silver-nanoparticles against Staphylococcus aureus and Escherichia coli. Korean Journal of Microbiology and Biotechnology. 39, 77 85 .

Rai., Deshmukh, S., Ingle, A. and Gade, A. (2012). Silver nanoparticles: the powerful Nano weapon against multidrug-resistant bacteria. Journal of applied microbiology. 112, 841-852.

Salomoni, R., Leo, P. and Rodrigues, M.( 2015). Antibacterial activity of silver nanoparticles (AgNPs) in Staphylococcus aureus and cytotoxicity effect in mammalian cells. The Battle Against Microbial Pathogens: Basic Science, Technological Advances and Educational Programs (A. Mendez-Vilas, Ed.) pp:851-857.

Peters, R. J., Bouwmeester, H., Gottardo, S., Amenta, V., Arena, M., Brandhoff, P., Marvin, H. J., Mech, A., Moniz, F. B. and Pesudo, L. Q. (2016). Nanomaterials for products and application in agriculture, feed and food. Trends in Food Science \& Technology. 54, 155-164. 
Winn, W. C., \& Koneman, E. W. (2006). Koneman's color atlas and textbook of diagnostic microbiology. Philadelphia: Lippincott Williams \& Wilkins. 6th edition.

. Clinical and Laboratory Standards Institute. Performance standards for antimicrobial susceptibility testing.(2016). 26th edition.

Kumar D, Singh AK, Ali MR, Chander Y(2014). Antimicrobial susceptibility profile of extended spectrum $\beta$ Lactamase (ESBL) producing Escherichia coli from various clinical samples. Infected Disease. 7:1-8.

Caroff,N.; Espaze, E.; Berard, I.; Richet, H.; Reynaud, A.(1999).Mutations in the ampC promoter of Escherichia coli isolates resistant to oxyiminocephalosporins without extended spectrum $\beta$-lactamase production .FEMS Microbiology Letters ,137:459-465.

.Maynard,C.;Fairbrother,J.;Bekal,S.;Sanschagrin,F.;Levesque,R.;Brousseau,R.;Masson,L.;Lariviere,S.;Harel,J.(2 003).Antimicrobial Resistance Genes in Enterotoxigenic Escherichia coli O149:K91 Isolates Obtained over a 23year period from Pigs. Antimicrobial Agents and Chemotherapy.47 (10):3214-3221.

Ansari, M.A.; Haris, M.K.; Aijaz, A.K.; Asfia, S.; Ameer, A. (2009). Synthesis and characterization of the antibacterial potential of $\mathrm{ZnO}$ nanoparticles against extended-spectrum $\beta$-lactamase-producing $\mathrm{E}$. coli and $\mathrm{K}$. pneumoniae isolated from a tertiary care hospital of North India. Applied Microbiology and Biotechnology |10:3733-3736.

Amsterdam, D. (1996). Susceptibility testing of antimicrobials in liquid media. In: Loman, V., ed. Antibiotics in laboratory Medicine, 4th ed. Williams and Wilkins, Baltimore, MD.: 52-111.

Y. S. Yang, C. H. Ku, J. C. Lin .(2010) Impact of extended-spectrum $\beta$-lactamase (ESBLs)-producing Escherichia coli and Klebsiella pneumoniae on the outcome of community-onset bacteremic urinary tract infections," Journal of Microbiology, Immunology and Infection. Taiwan Society of Microbiology. 43( 3) , 194-199.

Siraj, S. M. ,S. Ali, and B. Wondafrash. (2015). "Extended-spectrum $\beta$-lactamase (ESBLs)-production in Klebsiella pneumoniae and Escherichia coli at Jimma University Specialized Hospital. South-West Ethiopia, ”BioPublisher. $5(1), 1-9$. 
Abayneh M., Getnet T., and Alemseged A.(2018). Isolation of Extended-Spectrum $\beta$-lactamase- (ESBL-) Producing Escherichia coli and Klebsiella pneumoniae from Patients with Community-Onset Urinary Tract Infections in Jimma University Specialized Hospital.Southwest Ethiopia Canadian Journal of Infectious Diseases and Medical Microbiology Article ID 4846159,.8 .

El-kersh, T. A, M. A. Marie, Y. A. Al-sheikh, and S. A. Al-kahtani. (2015) "Prevalence and risk factors of community-acquired urinary tract infections due to ESBLs-producing Gram negative bacteria in an Armed Forces Hospital in Southern Saudi Arabia," Global Advanced Research Journal of Medicine and Medical Science. 4( 7), $321-330$.

Moyo, S. J. ,S. Aboud, M. Kasubi, E. F. Lyamuya, and S. Y. Maselle, (2010).“Antimicrobial resistance among producers and non-producers of extended spectrum $\beta$-lactamases (ESBLs) in urinary isolates at a tertiary Hospital in Tanzania," BMC Research Notes. 3(1), 348.

Kang, S. H. K. , Ji-W. H.-B. K. Bang, E.-C. K. Nam-Joong Kim (2006). "Community-acquired versus nosocomial Klebsiella pneumoniae bacteremia : clinical features, treatment outcomes, and clinical implication of antimicrobial resistance," Journal of Korean Medical Science. 12(5) , 816-822.

Kader, A. A. , A. Kumar, and K. A. Kamath .(2007). "Fecal carriage of extended-spectrum $\beta$-lactamase (ESBLs)producing Escherichia coli and Klebsiella pneumoniae in patients and asymptomatic healthy individuals," Infection Control and Hospital Epidemiology, 28( 9) , 1114-1116.

Neelam Taneja, Pooja Rao, Jitender Arora \& Ashok Dogra (2008). Occurrence of ESBL \& AmpC $\beta$-lactamases \& susceptibility to newer antimicrobial agents in complicated UTI. Indian J. Med. Res. 127, pp 85-88.

ALshamarti, M.J and Abaas Sh. Jwad AL-Muhnna

(2011) Molecular Detection of AmpC Gene Encoding Antibiotic Resistance among Klebsiella spp. Isolated from Different Infections. Journal of Al-Kufa University Journal for Biology..3 (1),1-9.

Majdalawieh,, A., Kanan, M. C., EL-kadre, O. and Kanan, S. M. (2014). Recent advances in gold and silver nanoparticles: synthesis and applications. Journal of nanoscience and nanotechnology. 14, 4757-4780.

Peters, R. J., Bouwmeester, H., Gottardo, S., Amenta, V., Arena, M., Brandhoff, P., MARVIN, H. J., Mech, A., MonizZ, F. B.and Pesudo, L. Q. (2016). Nanomaterials for products and application in agriculture, feed and food. Trends in Food Science \& Technology. 54, 155-164. 
Singh, P. K., Jairath, G. and Ahiawat, S. S. (2016). Nanotechnology: a future tool to improve quality and safety in meat industry. Journal of food science and technology. 53, 1739-1749.

Jung ,W. K. Hye Ch. K. Ki Woo K. Sook Sh. So Hyun K. and Yong Ho P. (2008).Antibacterial Activity and Mechanism of Action of the Silver Ion in Staphylococcus aureus and Escherichia coli. Applied and Enviromental Microbiolgy. Vol. 74, No. 7, p. 2171-2178. 